\title{
RECENT JUDICIAL DEVELOPMENTS OF INTEREST TO ENERGY LAWYERS
}

\author{
SONYA MORGAN, MichaEL J. DONALDSON, \\ AND ROBERT WOOD*
}

This article summarizes a number of recent judgments applicable to the energy sector. Topics touched upon include the interpretation of freehold leases, rights of first refusal, farmout and royalty agreements, applicable limitation periods, recent developments in tort and civil procedure, and aboriginal and competition law.
Cet article résume plusieurs jugements récents qui s'appliquent au secteur énergétique. Les sujets concernent non seulement l'interprétation de baux francs, les droits du premier refus, l'amodiation et les accords de redevances, les délais de prescriptions extinctives applicables, les derniers développements dans les poursuites civiles et en responsabilité délictuelle ainsi que le droit des Autochtones et la loi sur la concurrence.

\section{TABLE OF ConTENTS}

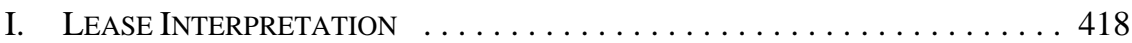

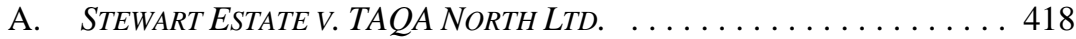

II. FARMOUT AGREEMENTS . . . . . . . . . . . . . . . . . . . . . . 425

A. EOG RESOURCES CANADA V.

UNCONVENTIONAL GAS RESOURCES CANADA OPERATING INC. . . . . 425

III. RIGHTS OF FiRST REFUSAL . . . . . . . . . . . . . . . . . . . . . . . . . . . . . . 427

A. BLAZE ENERGY LTD. V. IMPERIAL OIL RESOURCES . . . . . . . . . . . 427

IV. Limitation PERIOdS ANd ROYAlty Claims . . . . . . . . . . . . . . . . 429

A. CANADIAN NATURAL RESOURCES LTD. V.

JENSEN RESOURCES LTD. . . . . . . . . . . . . . . . . . . . . . . . . . . 429

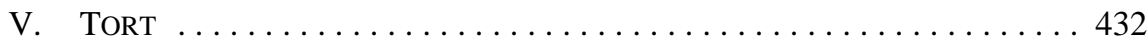

A. A.I. ENTERPRISES LTD. V. BRAM ENTERPRISES LTD. . . . . . . . . . . 432

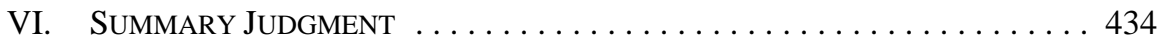

A. ENCANA CORPORATION V. ARC RESOURCES LTD. . . . . . . . . . . 434

B. HRYNIAK V. MAULDIN . . . . . . . . . . . . . . . . . 434

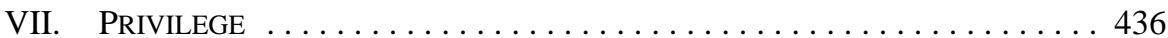

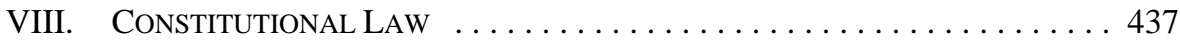

A. DANIELS V. EOG RESOURCES CANADA INC. . . . . . . . . . . . . . 437

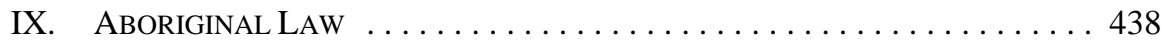

A. BEHN V. MOULTON CONTRACTING LTD . . . . . . . . . . . . . 438

B. Moulton Contracting LtD. V. BRItish Columbia . . . . . . . . . 439

C. PENN West Petroleum LtD. V. OMinAYAK . . . . . . . . . . . . . 441

D. DENE THA' FIRST NATION V.

BRITISH COLUMBIA (MINISTER OF ENERGY AND MINES) . . . . . . . . 441

E. BUFFALO RIVER DENE NATION V.

SASKATCHEWAN (MINISTER OF ENERGY AND RESOURCES) . . . . . . 442

X. StATUTORY INTERPRETATION $\ldots \ldots \ldots \ldots \ldots \ldots \ldots \ldots \ldots \ldots \ldots \ldots$ 
A. ENBRIDGE GAS NEW BRUNSWICK LIMITED PARTNERSHIP

V. NEW BRUNSWICK (ATTORNEY GENERAL) . . . . . . . . . . . . . 443

XI. StANDARD OF REVIEW . . . . . . . . . . . . . . . . . . . . . . . 444

A. SHIN HAN F \& P INC. V.

CANADA-Nova SCOTIA OFFSHORE PETROLEUM BOARD . . . . . . . . . 444

B. AREVA RESOURCES CANADA INC. V. SASKATCHEWAN

(MINISTER OF ENERGY AND RESOURCES) . . . . . . . . . . . . 444

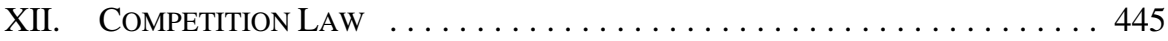

A. TERVITA CORP. V. COMMISSIONER OF COMPETITION . . . . . . . . 445

B. 321665 ALBERTA LTD V EXXONMOBIL CANADA LTD. . . . . . . . . . . . 447

XIII. WorkPlace AlcoHol (DRUG) TESTING . . . . . . . . . . . . . 448

A. COMMUNICATION, ENERGY AND PAPERWORKERS

UNION OF CANADA, LOCAL 30 V. IRVING PULP \& PAPER, LTD. . . . . 448

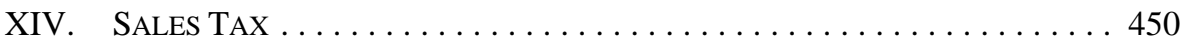

A. HUSKY OIL OPERATIONS LTD V.

SASKATCHEWAN (MINISTER OF FINANCE) . . . . . . . . . . . 450

XV. Administrative Tribunal Leave to Appeal Procedure . . . . . . . 451

A. FORT MCKAY FIRST NATION V.

ALBERTA ENERGY REGULATOR

\section{LEASE INTERPRETATION}

\section{A. STEWART ESTATE V. TAQA NORTH LTD. ${ }^{1}$}

Under a lease that allows shut-in for "lack of or intermittent market" or "circumstances beyond the Lessee's reasonable control," the operator can shut-in a well where there is zero or nominal return

\section{INTRODUCTION}

In this case (which is on its way to the Alberta Court of Appeal), the plaintiff lessors and top-lessee sought a declaration that five freehold petroleum and natural gas leases had terminated for non-production. From 1995 to 2001, the operator had ceased operations and production from the well at issue because the leased substances could not be produced economically. The plaintiffs sought damages on the basis of disgorgement of subsequent profits. Justice Romaine dismissed the plaintiffs' claims, deciding that:

- A six year shut-in did not cause termination of the lease because the well's poor economics were due to "lack of or an intermittent market" or "circumstances beyond the Lessee's reasonable control."

- The plaintiff lessors' claims were limitation barred because they were under a duty to investigate the reasons for the shut-in when they began to receive shut-in royalties. 
- $\quad$ The top-lessee plaintiff had not engaged in champerty and maintenance and had standing to sue for declaratory relief, but no right to sue for damages.

- Some lessors who had assigned their interests to parties that were not before the Court had no standing to sue.

\section{FACTS}

Five 1960s leases provided (with minor variations between them):

- A 10-year primary term, with the lease continuing so long thereafter as there is production from the lands.

- $\quad$ After the primary term, the lease will remain in force if production ceases, so long as the lessee commences further drilling or operations within 90 days, and operations continue and result in production.

- $\quad$ Four of the five leases contain a "Third Proviso" (subject to minor variations in language) that, after the primary term, "if ... any well ... is shut-in, capped, suspended or otherwise not produced as the result of a lack of or an intermittent market, or any cause whatsoever beyond the Lessee's reasonable control, the time of such interruption or suspension or non-production shall not be counted against the Lessee,” and the lease will remain in force. ${ }^{2}$

- The fifth lease contains a similarly worded Third Proviso: "if drilling, working or production operations are interrupted or suspended as a result of any cause whatsoever beyond the Lessee's reasonable control including, in the case of production operations, lack of or an intermittent market, the time of such interruption or suspension shall not be counted against the Lessee.”3

- A 12.5 percent royalty to the lessor in respect of the substances produced and marketed from the leased lands.

In 1968, the then-lessees under the five leases pooled their interests under a Pooling Agreement so that any production or deemed production of leased substances from 25-271W5M (near Crossfield, Alberta) would continue all of the leases. In September 1968 (during the primary term) one of the lessees drilled the well at issue in this case: 7-25-271W5M (the 7-25 Well).

A brief history of the 7-25 well is:

- Two potentially producing formations were discovered: the BQ and Crossfield formations. 
- While the initial target for drilling was the Crossfield formation, for various reasons relating to transportation and processing, gas was initially produced from the BQ formation.

- $\quad$ The well produced gas from the BQ formation from March 1971.

- The well was completed in the Crossfield formation in May 1978.

- $\quad$ Production from the BQ formation continued until June 1980, subject to certain cessations in production.

- $\quad$ Production from the BQ formation was suspended in September 1980 and perforations cemented.

- $\quad$ Production commenced from the Crossfield formation in March 1981 and continued through July 1995, subject to certain cessations in production.

- $\quad$ The operator decided to shut in the well on 1 August 1995.

- $\quad$ From August 1995 through January 2001, the then-lessees paid shut-in royalty payments to the then-lessors.

- In November 2000, one of the working interest holders (Triquest) circulated an Independent Operations Notice to the other working interest holders with respect to its intention to re-enter and re-complete the well in the BQ formation and begin producing gas from that formation.

- $\quad$ Triquest perforated the well on 19 January 2001 and fracture-stimulated the well on 21 January 2001.

- The well was put back on production in the BQ formation in February 2001.

- $\quad$ The statement of claim was filed in August 2005.

- In January 2011, the well was shut-in by court order pursuant to an interim injunction issued in separate litigation. ${ }^{4}$

The plaintiffs argued that the Third Proviso did not apply in the circumstances to allow the lessees to shut in the well, and the leases had therefore terminated in 1995.

Much of the evidence at trial pertained to the history of the well and whether it was uneconomic to produce from 1995 to 2001 . The Court generally concluded that there was no economic market for production during the shut-in period. ${ }^{5}$ 


\section{THE CONTRACT INTERPRETATION ISSUE: DECISION AND COMMENTARY}

The Court held that the defendant lessees had the onus of establishing that the well was shut in "as the result of a lack of or an intermittent market, or any cause whatsoever beyond the Lessee's reasonable control" or, "as the result of any cause whatsoever beyond the Lessee's reasonable control, including ... lack of or an intermittent market.”6

The lessees argued that the words "lack of or an intermittent market" should be interpreted as "uneconomic or unprofitable market" and that the well was shut in for causes beyond the lessees' reasonable control. ${ }^{7}$ The plaintiffs argued that this interpretation would result in adding implied terms to the lease ("uneconomic or unprofitable"), ${ }^{8}$ that the lease should be interpreted strictly and narrowly, and the language "any cause whatsoever beyond the Lessee's reasonable control” referred only to force majeure type events and not to production that was always possible, even if uneconomic. ${ }^{9}$

The Court identified the main issue as whether the defendant lessees or their predecessors were required to operate the well at a loss or nominal return in order to preserve and continue the leases. ${ }^{10}$ The Court concluded that they were not, relying on the Court of Appeal's decision in Omers Energy Inc. v. Energy Resources Conservation Board (Alta), ${ }^{11}$ and distinguishing the Court of Appeal's decision in Freyberg v. Fletcher Challenge Oil and Gas Inc. ${ }^{12}$ : "I find that the phrase 'lack of or an intermittent market', read in context and with a view to the reasonable intention of parties to a lease to profit from the extraction of leased substances, should be interpreted to mean lack of or an intermittent economical or profitable market."13

The Court also concluded that the language "any cause whosoever beyond the Lessee's reasonable control" was not limited to instances of force majeure. This language applied to extend the lease because "it was uneconomical to produce during the shut-in period given the low price of gas and the relatively high costs of production and processing, effectively a lack of an economic market."14

Interestingly, Romaine J. was also the trial judge in Freyberg. ${ }^{15}$ The Court of Appeal overturned her decision in that case (that the lease continued) in part on the basis that she had erred in implying terms into the lease rather than interpreting it strictly. ${ }^{16}$ On the other hand,

Ibid at para 514.

Ibid at para 515.

Ibid at para 537.

Ibid at para 516 .

Ibid at para 1.

Ibid at paras 522-30, citing Omers Energy Inc v Energy Resources Conservation Board (Alta), 2011 ABCA 251, 513 AR 292 [Omers].

Stewart Estate, ibid at para 537, citing Freyberg v Fletcher Challenge Oil and Gas Inc, 2005 ABCA 46, 363 AR 35 [Freyberg].

Stewart Estate, ibid at para 542.

Ibid at para 568 .

Freyberg v Fletcher Challenge Oil \& Gas Inc, 2002 ABQB 692, 323 AR 45.

Freyberg, supra note 12 at paras 44-68. The lease in Freyberg contained express language allowing shut-in "as the result of a lack or an intermittent or uneconomic or unprofitable market" (ibid at para 27 [emphasis added]), so the same issue of implied terms did not arise there. The Court of Appeal in Freyberg also overturned the trial judge's factual determination that it was uneconomic or unprofitable to produce from the well (ibid at para 84). 
the Alberta Court of Appeal itself implied terms into an oil and gas lease in Omers "meaningful quantities" — on the basis that it better reflected the intent of the parties. ${ }^{17}$ The inconsistency between Omers and other Canadian oil and gas jurisprudence was recently reviewed at this conference, ${ }^{18}$ and it will be interesting to see how the Court of Appeal resolves the interpretation issues in Stewart Estate, and whether the Court addresses the arguable discrepancies in approach between Freyberg and Omers.

\section{The Limitations IsSUE: DeCISION AND COMMENTARY}

The Court also concluded that the plaintiffs' claims were statute-barred by the two year limitation period. The well did not produce from 1995 to 2001, but the statement of claim was not filed until August 2005.

The Limitations Act, section 3(1)(a) immunizes defendants from liability if a claimant does not seek a remedial order within:

(a) 2 years after the date on which the claimant first knew, or in the circumstances ought to have known,

(i) that the injury for which the claimant seeks a remedial order had occurred,

(ii) that the injury was attributable to conduct of the defendant, and

(iii) that the injury, assuming liability on the part of the defendant, warrants bringing a proceeding. ${ }^{19}$

The Limitations Act defines "injury" to include "economic loss," "non-performance of an obligation” or, if nothing else applies, "the breach of a duty.",20

A brief history of the litigation as described by the trial judge is as follows:

- In 2001, one of the elderly lessees gave her son (Mr. O’Neill) a power of attorney over her affairs. Prior to this, Mr. O’Neill knew very little about the production or nonproduction of the 7-25 Well, other than a general family knowledge that the lease existed.

- In 2003, while reviewing his mother's affairs, Mr. O’Neill noticed what he thought to be discrepancies in some of the lease payments.

- In July 2003, one of the lessees, ExxonMobil, notified Mr. O’Neill that it had overpaid royalties.

Alicia Quesnel \& Aaron Rogers, “Assessment and Analysis of the Decision of the Alberta Court of Appeal in Omers Energy v. Alberta (Energy Resources Conservation Board)” (2012) 50:2 Alta L Rev 337 at 343.

19 RSA 2000, c L-12, s 3(1)(a).

Ibid, s 1(e). 
- Mr. O’Neill became concerned that ExxonMobil was preparing to sue for the overpayment and, in mid-2003, decided to seek legal advice.

- In late 2003, counsel for Mr. O’Neill and one of the other lessees advised that there may be issues with the validity of the lease and contacted ExxonMobil and Nexen about his client's concerns.

- The statement of claim was filed on 9 August $2005 .^{21}$

The Court concluded the plaintiffs reasonably ought to have known that the "injury" had occurred by November 1995 because they were receiving annual shut-in royalty payments instead of monthly production royalty cheques and the maximum 90-day shut-in period had elapsed..$^{22}$ Even if the plaintiffs did not know the reason for the cessation of production, or whether it was for reasons permitted under the Third Proviso, "they were not entitled to ignore the issue until they were notified of the reasons by the Defendants, but were obliged to exercise due diligence in determining the reason for the cessation of production."23 Reasonable diligence, the Court concluded, could have produced the necessary knowledge within a year. ${ }^{24}$ The plaintiffs' claim was filed more than two years after this. ${ }^{25}$

The Alberta Court of Appeal has recently put a more significant onus on claimants to take steps to investigate a potential claim, ${ }^{26}$ and the decision in Stewart Estate is arguably in line with this recent authority. Nonetheless, it seems to place a high onus on the claimants and could have the unintended consequence of encouraging litigation of questionable claims because of the claimant's fear of losing the right to sue. By making shut-in royalty payments, the defendants were essentially asserting that their circumstances fell within the relevant provision of the contract. Why would the plaintiff know about the "injury" - i.e. economic loss or breach of an obligation - when the defendants were purporting to act in accordance with the provisions of the contract? The result of the trial judge's interpretation is that, every time a well is shut-in or a lessor receives a shut-in royalty payment, the lessor should require the lessee to provide economic justification. Will the lessee be willing to disclose this information to the satisfaction of the lessor, or will the lessor be forced to commence an action simply to preserve rights and complete an investigation? The Court of Appeal may answer some of these questions in Stewart Estate, or we may have to wait for future cases to learn the answers to these questions.

\section{THE DAMAGES IsSUE}

While addressed only in the alternative, the Court also considered the appropriate measure of damages if the leases had terminated. The Court adopted the Freyberg Damages

Stewart Estate, supra note 1 at paras 47-63.

Ibid at para 197.

Ibid at para 200.

Ibid.

The Trial Judge also allowed that there may be an issue about whether the cause of action accrued at the end of the shut-in period instead, but in any instance the end of the shut-in period, January 2001, was still more than 2 years before the claim was filed (ibid at para 207).

26 See Canadian Natural Resources Ltd v Jensen Resources Ltd, 2013 ABCA 399, 566 AR 76 [Jensen], discussed below. 
reasoning, ${ }^{27}$ and relied heavily on Professor Percy and David McGillivray's article "Overlapping Remedies and the Unexpected Termination of Oil and Gas Leases."28 The Court concluded that

[h] ad I found the leases to be invalid, I would have found that the Defendants were innocent tortfeasors who acted in the mistaken belief that they were acting lawfully. Thus, the options for damages in restitution would be either a form of the "mild" rule of disgorgement or the royalty approach adopted in Williston Wildcatters and the Freyberg Damages Decision.

In this case, I would find a royalty and bonus approach to be the most appropriate. ${ }^{29}$

\section{THE MAINTENANCE AND CHAMPERTY ISSUE}

The defendants Nexen, ExxonMobil, and Coastal asserted a counter-claim in champerty and maintenance against 1088924 Alberta Ltd., which had funded the plaintiffs litigation. The trial judge found the facts as follows:

- In July 2004, counsel for the plaintiff lessors contacted FSI, an oil and gas company in the business of acting on behalf of lessors who have limited experience in oil and gas disputes.

- In November 2004, FSI agreed to:

- $\quad$ top-lease if the existing leases were be found to be invalid and pay royalties at 20 percent if the existing leases had terminated.

- $\quad$ pay any legal costs arising from any necessary action.

- $\quad$ split 50 percent of any damages recovered with the plaintiff lessors.

- $\quad$ Other plaintiffs later signed on with FSI under generally the same terms.

- $\quad$ FSI subsequently transferred the agreements (and further supplemental agreements) to 1088924 Alberta Ltd., which held the top leases in trust for FSI and had registered caveats. $^{30}$

The Court dismissed the maintenance and champerty counterclaim ${ }^{31}$ but did say this type of situation could be addressed in costs: "[w]hile this conduct raises genuine concerns, I am satisfied that the top-lessees have a commercial interest arising from the top-leases sufficient

Freyberg v Fletcher Challenge Oil \& Gas Inc, 2007 ABQB 353, 428 AR 102 [Freyberg Damages]. David R Percy \& David McGillvray, “Overlapping Remedies and the Unexpected Termination of Oil and Gas Leases” (2011) 49:2 Alta L Rev 251; see also Stewart Estate, supra note 1 at para 631. Stewart Estate, ibid at paras 662, 665.

Ibid at paras 5-6, 56-63.

Ibid at paras 680-90. 
to save them from a charge of maintenance. Concerns about any impropriety in their role in the litigation can be addressed through the mechanism of costs."32

\section{OTHER MATTERS ADDRESSED}

The Court also dealt with several other matters not addressed in this article:

- Some of the plaintiffs had assigned their interests in two of the leases to other interested parties not before the Court and therefore these plaintiffs' claims could not succeed on that basis alone. ${ }^{33}$

- The top-lessee plaintiff had standing before the Court on the issue of lease validity but no standing to claim damages. ${ }^{34}$

- None of the claims were barred in whole or in part by estoppel, laches, or acquiescence. $^{35}$

- The defendants' counterclaim for intentional interference with contractual relations failed because there was no unlawful act. ${ }^{36}$

\section{FARMOUT AgREEMENTS}

A. EOG RESOURCES CANADA V.

UNCONVENTIONAL GAS RESOURCES CANADA OPERATING INC. ${ }^{37}$

Farmin agreement incorporating CAPL Farmout and Royalty Procedure requires a notice of default to be served before a conditional interest in land can be terminated

\section{BACKGROUND}

This case addresses whether a farmee (EOG) lost its right under a Farmin Agreement to continue the work necessary to earn an interest in the lands. It offers a rather context-specific analysis of the interaction between the Canadian Association of Petroleum Landmen Farmout and Royalty Procedure (the CAPL Procedure), the parties' Farmin Agreement, and a subsequent amending agreement. Nonetheless it does offer an interpretation of the $C A P L$

Ibid at para 690.

Ibid at paras 171-75.

Ibid at paras 176-82.

Ibid at paras 220-25.

Ibid at paras 691-92, relying on Polar Ice Express Inc v Arctic Glacier Inc, 2007 ABQB 717, 434 AR 261, aff'd 2009 ABCA 20, 446 AR 295 [Polar Ice], a case which treats the tort as equivalent to unlawful interference with economic interests. Note this aspect of the decision relied on case law pre-dating $A I$ Enterprises Ltd v Bram Enterprises Ltd, 2014 SCC 12, [2014] 1 SCR 177 [AI Enterprises], discussed below. The Supreme Court in AI Enterprises did not specify how the tort of "intentional interference with contractual relations" should be treated but we can presume it has been subsumed into the tort of unlawful interference with economic relations, now referred to in AI Enterprises as the "unlawful means" tort.

372013 ABQB 105, [2013] AJ No 183 (QL) [EOG]. 
Procedure that says notice of default may be required even when the farmee is still in the process of earning its interest. ${ }^{38}$

\section{FACTS}

Unconventional Gas Resources Canada Operating Inc. (UGR) agreed to farm out 75 percent of its working interest to EOG if EOG spudded the well, continuously conducted drilling operations, and cased and completed the well to the contract depth. Subsequent amendments to the Farmin Agreement set a 30 September 2011 deadline, but what exactly had to be done by that deadline was unclear. ${ }^{39}$ Clause 5 of the Farmin Agreement stated: "[p]rovided Farmee has performed all of its obligations and requirements pursuant to Clause 4 of this Agreement ... then the Farmee shall have earned $75 \%$ of the Farmor's working interest in the Farmout Lands." 40 EOG spudded the well by the agreed upon deadline, but there was disagreement about whether it complied with its subsequent contractual obligations. $^{41}$

The Farmin Agreement incorporated by reference the CAPL Procedure. Section 13.1.A of the CAPL Procedure provides that if the farmee fails to spud the test well or commence any other operation as provided in the head agreement, the farmee's right to conduct operations terminates. ${ }^{42}$ The Court concluded that this section did not apply on the facts, because EOG had already spudded the well (the only operation for which the Farmin Agreement had set a date). ${ }^{43}$

\section{Section 13.1.C of the CAPL Procedure provides that}

\footnotetext{
if the Farmee is in default of "any of its obligations ... under the Head Agreement [Farmin Agreement], other than as provided in the preceding Subclauses" the Farmor may give the Farmee notice of the default with the Farmee to have 30 days to remedy the default, failing which the Farmor may, by notice, terminate all or any portion of the interest of the Farmee acquired in the Farmout lands. ${ }^{44}$
}

UGR argued that the notice of default requirement did not apply when the farmee had not met the conditions required to earn the working interest; section 13.1.C only applies once the farmee has already earned the working interest. ${ }^{45}$

\section{DECISION}

Master Hanebury disagreed, holding that Section 13.1.C applies to interests that are being earned. ${ }^{46}$ Because EOG spudded the well, it had a conditional or contingent interest. Master Hanebury concluded that, even if EOG had not met the Farmin Agreement's deadline for the

Ibid at paras 41-49.

Ibid at paras 3-8.

Ibid at para 28.

Ibid at paras 12-21.

Ibid at para 42.

Ibid at paras 41-43.

Ibid at para 44.

Ibid at para 45.

Ibid at para 46. 
completion of work (which she was not willing to decide on a summary basis), UGR was required to serve a notice of default and give EOG an opportunity to cure the default. ${ }^{47}$ Because UGR had not done so, EOG continued to have an interest under the Farmin Agreement. $^{48}$

\section{COMMENTARY}

This appears to be a reasonable result in the circumstances. As pointed out by the Master, once the farmee has spent the money to spud the well in accordance with its obligations under the agreement, it seems unduly harsh for the farmee to lose its interest (albeit an inchoate one) without notice of its default and an opportunity to cure it. ${ }^{49}$ Moreover, it is probably fair to say that most farmors would prefer that the obligation well get drilled and completed (in other words, that the contract be performed) rather than see a forfeiture of the farmee's contingent interest. The requirement to give notice of default does not seem overly onerous or too technical.

\section{RightS OF FIRST REFUSAL}

\section{A. BLAZE ENERGY LTD. V. IMPERIAL OIL RESOURCES $S^{50}$}

Court interprets ROFR agreements in larger sale transaction; ROFR attaches only to asset identified in ROFR agreement - not any other assets in the larger transaction

\section{BACKGROUND}

In a multi-asset sale, parties are often required to interpret agreements that contain rights of first refusal (ROFR) that apply only to some of the assets being sold. Without specific case law confirmation, the typical approach has been that only those assets specifically identified in a ROFR agreement are subject to the ROFR. The Alberta Court of Queen's Bench has now affirmed this approach.

\section{2. $\quad$ FACTS}

Imperial Oil Resources sold a package of assets to Whitecap Resources Inc. for \$855 million, which included (amongst other assets) Imperial's 90 percent interest in the 6-28 West Pembina Gas Plant (the Plant) and its working interest in the surrounding West Pembina Area lands. Immediately after the Whitecap-Imperial sale was to close, Whitecap intended to sell to Keyera 94.4 percent of the 90 percent interest in the Plant it was acquiring from Imperial (meaning Keyera would acquire an 85 percent interest and Whitecap would retain a 5 percent interest in the Plant), and a portion of the West Pembina Area lands for $\$ 113$ million. 
The sale of the Plant was subject to a ROFR contained in a 1988 Construction Ownership and Operation Agreement (CO\&O Agreement) to which Blaze Energy Ltd. and Imperial were parties. The ROFR was triggered "[i]f an Owner ... wishes to dispose of all or any portion of its interest in the Plant." ${ }^{\text {51 }}$ Article 1101 of the CO\&O Agreement provided an exception in certain circumstances where the sale of the Plant was part of a larger sale: "[a]ny owner may, without restriction, dispose of an interest in the Plant in conjunction with the disposal of the Owner's corresponding working interest in the lands in the West Pembina Area from which Gas is being produced by the Plant." ${ }^{, 52}$

Blaze also had a ROFR over a portion of the lands located in the West Pembina Area, in accordance with a 1960 operating agreement (1960 Lands Agreement). Clause 18 of the 1960 Lands Agreement provided:

In the event any party desires to sell all or any part of his or its interests which are subject to this agreement, the other party or parties hereto shall have a preferential right to purchase the same. In such event ... said other party or parties ... shall thereupon have an option ... to purchase such interest at and for the offered price and upon the offered terms. ${ }^{53}$

Pursuant to the 1960 Lands Agreement, Blaze was offered a ROFR over both of the sales of the 1960 Lands (once in the Imperial-Whitecap sale and again in the Whitecap-Keyera sale), but was not offered a ROFR over the sale of the Plant on the basis of the Article 1101 exception.

Blaze argued that it was entitled to a ROFR over the sale of the Plant on two grounds:

1. The 1960 Lands Agreement required it: Clause 18, and specifically the language "for the offered price and upon the offered terms," created a contractual right to an interest in the Plant. Blaze argued that a ROFR must be offered over the Plant because it was being sold as part of the sale of the 1960 Lands. $^{54}$

2. The exception contained in the CO\&O Agreement did not apply: the sale of the interest in the Plant from Whitecap to Keyera did not "correspond" with a sale of the West Pembina Area lands. ${ }^{55}$

\section{DECISION}

The Court rejected both of Blaze's arguments. With respect to the 1960 Lands Agreement, the Court held that Clause 18 was not intended to include the Plant, which was built years after the ROFR on the 1960 Lands was given. The ROFR applied only to those assets specifically subject to the 1960 Lands Agreement. 
With respect to the CO\&O Agreement, the Court noted that the portion of the West Pembina Area lands Whitecap subsequently sold to Keyera were all of the properties in the West Pembina Area that primarily produce gas. The lands in the West Pembina Area that Whitecap was keeping and not selling on to Keyera comprised either non-producing lands or properties that primarily produce crude oil, with a small amount of gas produced incidentally as a by-product of the oil production. A calculation of relative natural gas production from the interest being sold to Keyera estimated production at the effective date of the transaction at 94.4 percent — which matched precisely the 94.4 percent Plant interest Keyera was acquiring. The Court held: “[t]he word 'corresponding' does not import a requirement that a disposing owner sell all of its interest in the Plant nor does the word 'corresponding' mean that a disposing owner must sell all of the lands from which gas is produced into the plant." 56 Therefore the exception to the ROFR requirement still applied. Blaze had no right to a ROFR over the sale of the Plant.

\section{DISCUSSION}

While this decision rests on specific facts and contractual language, its larger importance for oil and gas practitioners is to confirm that ROFRs apply only to those assets specifically listed in the ROFR agreement. This is particularly important in large multi-asset transactions. It also shows the courts' reluctance to adopt a strict (or strained) construction where that would conflict with the parties' intent in making the ROFR.

The other important point is a practice one: this case came to the Court as an expedited trial of three issues on consent. The Court showed significant flexibility in having the trial heard a few weeks after the statement of claim was filed. This corresponds with the Supreme Court's directive in Hryniak v. Mauldin. ${ }^{57}$ It is also consistent with the Alberta Courts' "open for business" approach to the need for expedited commercial decisions, and is something that parties should consider requesting in truly time-sensitive matters.

\section{Limitation PERiods AND Royalty Claims}

\section{A. CANADIAN NATURAL RESOURCES LTD. V. JENSEN RESOURCES LTD. ${ }^{58}$}

Court of Appeal varies trial judgment on contract interpretation and restricts James H. Meek Trust v. San Juan Resources Inc. to its facts on limitation periods

\section{BACKGROUND}

This is a Court of Appeal decision varying the trial decision reported in last year's CELF case law update. ${ }^{59}$ It adopts a less forgiving interpretation of "ought to have known" in 
section 3(1)(a) of the Limitations Act, ${ }^{60}$ likely making it harder for plaintiffs to justify a delay in bringing an action. In that way, it has some similarity with the trial judgment in Stewart Estate. $^{61}$

\section{2. $\quad$ FACTS}

This case involved the interpretation of two agreements that granted royalties:

- $\quad$ The 23 February 1978 letter agreement provided the employee (whose interest was assigned to the respondent Jensen) with “an assignment of an overriding royalty interest of $1 / 8$ th of $1 \%$ of all petroleum and natural gas produced and sold from any wells drilled on [employer's] leases and lands."62

- $\quad$ On 23 October 1978, the employer granted the employee a 0.25 percent gross overriding royalty (GOR) in all oil, natural gas, and other hydrocarbons in its 50 percent working interest in what the parties referred to as Section 32.

- A subsequent 4 January 1980 employment agreement purported to clarify the understanding reached in the 1978 letter agreement.

- $\quad$ In 1980 and 1981, the employer granted the employee GORs in sections 1 and 4.

- Later in 1981, the employee left the company. At this time, production from the three sections was governed by the employer's existing oil and gas leases.

- Due to regulatory changes, the Alberta government changed the definition of "oil sands" and effectively removed the oil deposits from the leases in relation to which the employee had been granted his GOR; then the employer received different oilsands leases over the same deposits.

- Gas production started from sections 1 and 32 in 1985, after the employee had left the company, but gas was never produced from section 4 .

- $\quad$ Oil was produced from section 4 in May 1997, section 32 in May 1999, and section 1 in December 2003.

- $\quad$ Royalties on section 32 were paid throughout production.

- $\quad$ Royalties were never paid on production from sections 1 and 4.

- Jensen did not issue its originating notice for the failure to pay royalties until 18 September 2009. ${ }^{63}$ 
As summarized by the Court of Appeal, the trial judge found that:

(a) The royalties granted over the original petroleum and natural gas leases were effective in attaching to production under the replacement oil sands leases, as the latter were issued "in lieu of" the former (reasons, paras. 53-5).

(b) The [1980] employment agreement was not relevant, as the wording of the royalty agreements was clear (reasons, paras. 51-2).

(c) [Jensen] was entitled to the royalties on oil production ... and no limitation period operated to limit its recovery because [Jensen] had "no clear information" that it had a claim prior to the expiration of the limitation period (reasons, paras 68-9). ${ }^{64}$

\section{DECISION AND COMMENTARY}

The Court of Appeal overturned the trial judge’s conclusions (b) and (c).

The Court of Appeal affirmed that multiple agreements concerning the same subject should be interpreted together unless expressly stated otherwise. ${ }^{65}$ The trial judge erred in simply holding that the employment agreement was not relevant. Nonetheless, reading the two agreements together, the result was the same: the employee had a GOR on substances produced under the replacement oilsands leases. ${ }^{66}$

The Court of Appeal overturned the trial judge's finding on limitations and concluded that the Limitations Act barred significant portions of Jensen's claim for missed royalty payments. But because each missed royalty payment is a new cause of action, Jensen was still entitled to all missed payments from and after 18 September 2007 — two years before the issuance of the originating notice. ${ }^{67}$

The Court of Appeal went out of its way to distinguish its previous statements in James H. Meek Trust v. San Juan Resources Inc., ${ }^{68}$ which had given the plaintiff much leeway in discoverability. In Meek, the Court said, "[a] royalty interest holder is entitled to expect the royalty payor to honour its obligations. Absent clear information to show improper payment, royalty interest holders are not obliged to take positive steps aimed at ensuring that they are being correctly paid." 69

But the Court of Appeal in Jensen limited that statement to its facts:

This passage is merely a comment on the facts in Meek. In that case the claimants were not involved in the oil industry, did not have easy access to material information, and "ought not to have known" of their claim at an earlier time. The reference to "clear information” did not (and could not) purport to amend the wording

Ibid at para 8.

Ibid at para 17.

Ibid at para 37.

Ibid at para 48 .

2005 ABCA 448, 376 AR 202 [Meek].

Ibid at para 33 . 
of the Limitations Act. The Act does not require "clear information", but rather specifies a test of when the claimant "ought to have known" of the claim. Meek at para. 21 recognized that "ought to have known" calls for "reasonable diligence" on the part of the claimant. There will be cases where the claimant will have sufficient knowledge to throw an obligation on it to make reasonable inquiries about its rights. That will start the running of the limitation period, even if the claimant's knowledge could not be described as "clear information to show improper payment.",70

The Court held that the trial judge erred in considering when the claimant had "clear information" rather than when the claimant "knew or ought to have known" that it had a claim. ${ }^{71}$ The Court of Appeal held that, when the employee became aware of production on section 32 in 1999, he could have made inquiries about equivalent production on sections 1 and $4 .^{72}$ He did not do so, and did not consult the available public resources that report hydrocarbon production in Alberta. ${ }^{73}$ Any claims for royalties payable more than two years before the originating notice were therefore statute barred. ${ }^{74}$

This seems to put a much higher onus on plaintiffs than Meek did. Why would anyone be required to investigate whether production on one section might mean there is production on another nearby section ${ }^{75}$ There is lots of publicly available information about all sorts of things; does "reasonable diligence" impose a positive duty to search public records for information that might reveal potential claims? This case does not go quite that far, but it does move much closer to the "could have known" end of the spectrum and away from the "no reason to suspect" approach taken in Meek.

One interesting issue the Court of Appeal may have to decide in Stewart Estate (discussed above) is how much subjective considerations affect what the statute arguably expresses as an objective test. No doubt the plaintiffs in Stewart Estate will argue that they were - like the Plaintiffs in Meek — "not involved in the industry" and did not have easy access to material information with which to determine they had suffered a loss. This case may give the Court an opportunity to clarify whether there is still room for the more relaxed Meek approach or whether the stricter standard imposed in Jensen will always apply.

\section{TORT}

\section{A. A.I. ENTERPRISES LTD. V. BRAM ENTERPRISES LTD. ${ }^{76}$}

Supreme Court narrows the ambit of unlawful interference with economic relations

The Supreme Court of Canada in A.I. Enterprises Ltd. v. Bram Enterprises Ltd. has significantly narrowed the tort of unlawful interference with economic interests. Stewart Estate (discussed above in Part I.A) summarized the then-existing three-part test for unlawful

Ibid at para 41 .

Ibid at para 42.

Ibid at paras 43-46.

Ibid at para 47.

Ibid at paras 48-49.

In this instance the plaintiff did admit he "had not been fully diligent in protecting the respondent's rights," (ibid at para 47) but surely "reasonable" rather than "full” diligence is the standard.

AI Enterprises, supra note 36. 
interference with economic interests: (1) the defendant intended to injure the plaintiff; (2) the means to accomplish this were unlawful; and (3) the plaintiff suffered economic loss as a result. ${ }^{77}$ The second element of this tort has at times been interpreted broadly. For example, the Ontario Court of Appeal in Reach M.D. Inc. v. Pharmaceutical Manufacturers Association of Canada held that the "unlawful" component of this tort can simply be an act that the defendant "was not at liberty to commit." expand the scope of tort liability. But more recently, some courts have been stepping away from such an expansive approach, instead following the narrower approach adopted by the House of Lords in OBG Ltd. v. Allan. ${ }^{79}$

Now the Supreme Court of Canada has weighed in, limiting the scope of the "unlawful means" tort in line with (though not identical to) the analysis in $O B G$. It described the rationale for this tort as "liability stretching" so that a plaintiff can sue for its own losses resulting from an actionable wrong committed by a defendant against a third party. The Court redefined the elements of the tort: ${ }^{80}$

\footnotetext{
The unlawful means tort creates a type of "parasitic" liability in a three-party situation: it allows a plaintiff to sue a defendant for economic loss resulting from the defendant's unlawful act against a third party.... While the elements of the tort have been described in a number of ways, its core captures the intentional infliction of economic injury on C (the plaintiff) by A (the defendant)'s use of unlawful means against B (the third party). ${ }^{81}$
}

The "intent" element requires that the defendant intend to either (a) "cause economic harm to the claimant as an end in itself," or (b) "cause economic harm to the claimant because it is a necessary means of achieving an end that serves some ulterior motive." ${ }^{22}$ Mere knowledge that the plaintiff will be harmed as a result of a course of conduct is not sufficient: "[i]t is the intentional targeting of the plaintiff by the defendant that justifies stretching the defendant's liability so as to afford the plaintiff a cause of action." ${ }^{\text {,3 }}$

To qualify as an "unlawful means" for the purpose of this tort, the conduct must give rise to a civil cause of action by the third party (or would do so if the third party had suffered loss as a result of that conduct).$^{84}$ The Court specifically noted the importance of keeping this tort within a narrow band (and thus narrowed the older test identified in Stewart Estate and Behn $v$. Moulton Contracting Ltd., discussed below) ${ }^{85}$ Breach of statute (including the Criminal Code) is not itself an unlawful act that the plaintiff can rely upon to satisfy this tort. ${ }^{86}$

Supra note 1 at para 691, citing Polar Ice, supra note 36 at paras 81-82.

(2003), 65 OR (3d) 30 at paras 50-52 (CA).

[2007] UKHL 21, [2008] 1 AC 1 [OBG]; see e.g. Correia v Canac Kitchens, 2008 ONCA 506, 91 OR (3d) 353.

AI Enterprises, supra note 36 at paras 43-49.

Ibid at para 23.

Ibid at para 95.

Ibid.

Ibid at paras 76, 86 .

Ibid at paras 5, 29-32; Stewart Estate, supra note 1; Behn v Moulton Contracting Ltd, 2013 SCC 26, [2013] 2 SCR 227 [Behn] (discussed below in Part IX.A).

AI Enterprises, ibid at para 45. 
In the course of its reasons, the Supreme Court of Canada addressed related economic torts, including unlawful means conspiracy and intimidation, and concluded that its change in the law of unlawful interference with economic relations does not necessarily mean that the "unlawful means" component of these other torts changes as well. ${ }^{87}$

The law of economic torts is in a state of flux.$^{88}$ Counsel considering whether a cause of action properly arises should not only look at their own province's appellate authority but review the Supreme Court's decision in AI Enterprises (and associated policy considerations) as well as post-OBG United Kingdom authority.

\section{SUMMARY JUDGMENT}

\section{A. ENCANA CORP. V. ARC RESOURCES LTD. ${ }^{89}$}

Summary judgment over title to coalbed methane granted on the basis of section 10.1 of the Mines and Minerals Act

To resolve the issue of ownership of coalbed methane, in December 2010 the Alberta Legislature amended the Mines and Minerals Act to add section 10.1, which provides (among other things) "[c]oalbed methane is hereby declared to be and at all times to have been natural gas." 90 This has resulted in summary judgment applications in extant litigation over coalbed methane ownership, including in these consolidated actions. These applications are a sequel to the summary applications addressed in the 2011 decision Encana Corp. v. ARC Resources Ltd. ${ }^{91}$

These summary judgment applications addressed whether section 10.1 of the Mines and Minerals Act conclusively resolved the issue of coalbed methane ownership such that there was no need for a trial. The Court in this 2013 case concluded it had, and that the mineral rights holder (rather than the coal rights owner) has the right to extract coalbed methane. Summary judgment was therefore granted.

\section{B. HRYNIAK V. MAULDIN ${ }^{92}$}

A possible change to the law of summary judgment in Alberta

Lawyers in Alberta are well-aware of the difficulty of obtaining summary judgment: it seems that as soon as facts are contested and a party claims an assessment of credibility is required, summary judgment is denied.

Ibid at paras 63-70. A number of cases appear to have treated the "unlawful means" element the same across economic torts. See e.g. Edmonton Regional Airports Authority v North West Geomatics Ltd, 2002 ABQB 1041, 329 AR 332 at para 122.

88 Note for example, the Supreme Court's recent questioning of "predominant purpose" conspiracy in ProSys Consultants Ltd v Microsoft Corporation, 2013 SCC 57, [2013] 3 SCR 477 at paras 74-75. 2013 ABQB 352, 564 AR 230.

RSA 2000, c M-17, s 10.1(1).

2011 ABQB 431, 523 AR 108, aff'd 2012 ABCA 271, 536 AR 199.

2014 SCC 7, [2014] 1 SCR 87 [Hryniak]; the Supreme Court applied the principles identified in this case in the associated case of Bruno Appliance and Furniture, Inc v Hryniak, 2014 SCC 8, [2014] 1 SCR 126. 
This is likely to change as a result of the Supreme Court of Canada's decision in Hryniak, which interpreted the Ontario summary judgment rule. Rule 20.04 requires the Court to grant summary judgment if "the court is satisfied that there is no genuine issue requiring a trial with respect to a claim or defence."93 The Ontario rule expressly permits the Court to weigh evidence, evaluate the credibility of a deponent, and draw any reasonable inference from the evidence. ${ }^{94}$ The Supreme Court did not, however, limit itself to interpreting the specific language of the Ontario rule, but more generally stated that a "cultural shift" is required to create an environment promoting quick and affordable access to justice; the summary judgment rules should be interpreted broadly in this manner. ${ }^{95}$ The Court highlighted the element of proportionality (now codified in the Alberta Rules of Court) ${ }^{96}$ and stated that, in considering whether summary judgment should be granted, "[t]he question is whether the added expense and delay of fact finding at trial is necessary to a fair process and just adjudication." 97

Does the Supreme Court's decision in Hryniak make summary judgment easier to obtain in Alberta? The first case from the Alberta Court of Appeal addressing this point arguably says “yes.” The Court of Appeal in Windsor v. Canadian Pacific Railway held that, in light of recent Supreme Court case law, including Hryniak, “[t]he modern test for summary judgment is therefore to examine the record to see if a disposition that is fair and just to both parties can be made on the existing record." 98 The Court of Appeal also confirmed that the principles stated in Hryniak are consistent with Alberta's summary judgment rule, ${ }^{99}$ making it hard to see Hryniak as applying only in Ontario.

In spite of the Court of Appeal's statements applying Hryniak in Alberta, the case does not expressly deal with whether Alberta's rule 7.3 permits summary judgment where the underlying facts are in dispute. Unlike Ontario's corresponding rule, rule 7.3 does not expressly provide judges with authority to weigh evidence and make determinations as to credibility - powers that the Supreme Court characterized in Hryniak as "new." 100 And the Alberta Court of Appeal in Windsor said "[t]rials are for determining facts, and the facts underlying this dispute are not seriously in issue.”101

Early Queen's Bench case law says disputes as to facts are to be addressed through the summary trial rules as opposed to the summary judgment procedure. In Orr v. Fort McKay First Nation $^{102}$ (which pre-dates the Court of Appeal's decision in Windsor) the Court of Queen's Bench distinguished Hyrniak on the basis that the Ontario summary judgment rules

Rules of Civil Procedure, RRO 1990, Reg 194, r 20.04(2)(b).

Ibid, r 20.04(2.1).

Hryniak, supra note 92 at paras 23-33.

Alta Reg 124/2010, r 1.2(4).

Hryniak, supra note 92 at para 33.

2014 ABCA 108, 94 Alta LR (5th) 301 at para 13 [Windsor]; as opposed to the arguably difficult-tosatisfy "no genuine issue for trial" and "plain and obvious" standard identified in cases like Murphy Oil Co v Predator Corp, 2006 ABCA 69, 384 AR 251 at para 24 [Murphy Oil].

Windsor, ibid at para 14; Alberta Rules of Court, supra note 96, r 7.3.

Hryniak, supra note 92 at para 66.

Windsor, supra note 98 at para 16; note that the Alberta Court of Appeal has always permitted at least some minimal weighing of the evidence to determine whether the applicant has shown there is no genuine issue for trial: see e.g. Murphy Oil, supra note 98 at para 25.

2014 ABQB 111, [2014] AJ No 204 (QL) [Orr]. 
were more akin to Alberta's summary trial rules, and that Alberta judges and masters are not permitted to weigh evidence on summary judgment as they are in Ontario. ${ }^{103}$

Counsel should keep in mind that this area is in a state of flux but should consider applications for summary judgment, or summary trial where facts are in dispute, which they may have rejected as likely to fail in the past.

\section{PRIVILEGe}

Two cases provided guidance on the scope of privilege this year - one from the Supreme Court of Canada and one from the Alberta Court of Appeal — largely confirming what many practitioners have assumed to be the law.

In Sable Offshore Energy Inc. v. Ameron International Corp. ${ }^{104}$ the Supreme Court of Canada considered whether privilege attaches to Pierringer agreements (where the plaintiff enters into settlement agreements with some but not all of the defendants). In Sable, the nonsettling defendants requested disclosure of the amounts paid under the settlement agreements (the settling parties had already disclosed the other terms).

The Supreme Court confirmed that the settlement amounts contained in Pierrenger agreements are subject to settlement privilege, and also confirmed that settlement privilege covers negotiations (successful or unsuccessful) in addition to any final agreement reached. The amount of the settlement would only be released once liability was determined at trial, to prevent over-recovery.

In TransAlta Corporation v. Market Surveillance Administrator, ${ }^{105}$ the Alberta Court of Appeal overturned a Queen's Bench decision that had allowed the Market Surveillance Administrator (MSA) access to records subject to litigation privilege. This case confirms that explicit statutory language is required before a party's common law privilege rights will be negated.

The Alberta Utilities' Commission Act gives the MSA investigative powers, including the power to demand and seize records "that are or may be relevant" for the purpose of an investigation. ${ }^{106}$ Section 50 provides a sealing process to be followed in the event a party

Ibid at paras 15-20. See also Whitecourt Power Limited Partnership v Interpro Technical Services Ltd, 2014 ABQB 135, 95 Alta LR 415, also pre-dating Windsor, where Master Mason relied on Orr and the Alberta summary trial rules to say that Alberta law is already consistent with the principles in Hryniak (at paras 36-41), concluding at paras 40-41

[i]f it is not possible to find the necessary facts, for example, due to conflicting affidavits, summary judgment cannot be granted in Alberta. This is because the Alberta court does not, in the context of a summary judgment application, have the enhanced fact-finding powers available the court in Ontario at the second stage of its summary judgment rule to weigh evidence and assess credibility. Those fact-finding powers expand the number of cases where there will be no genuine issue for trial.

In summary, the law in Alberta remains that if the robust review required of a master or justice in chambers reveals that it is necessary to assess the quality and weight of the evidence in order to make the requisite determination, summary judgment cannot be granted.

2013 SCC 37, [2013] 2 SCR 623 [Sable].

2014 ABCA 196, 100 Alta LR (5th) 52, s 46(1) [TransAlta].

SA 2007, с A-37.2, s 46(1). 
claims "solicitor-client privilege" over some of the records demanded. ${ }^{107}$ The Court of Queen's Bench had interpreted this provision to mean that a person required by the MSA to produce records had no right to claim litigation privilege. The Court of Appeal overturned this decision, adopting the Ontario Court of Appeal's statement that "fundamental common law privileges ... ought not to be taken as having been abrogated absent clear and explicit statutory language."108

\section{ConstituTional LAW}

\section{A. DANiEls V. EOG RESOURCES CANADA INC. ${ }^{109}$}

Application of Westcoast Energy test to conclude Manitoba pipeline delivering natural gas to a Manitoba-Saskatchewan undertaking is within provincial jurisdiction

This case does not create new law but distinguishes a pre-Westcoast Energy ${ }^{110}$ decision, Dome Petroleum Ltd. v. National Energy Board,${ }^{111}$ which held that a provincially-located storage cavern was an integrated part of an interprovincial undertaking and thus subject to federal jurisdiction.

EOG proposed a $32 \mathrm{~km}$ pipeline (the EOG Pipeline) in Manitoba from its oil battery to a riser facility to be built by Many Islands Pipe Lines (Canada) (MIPL) on the Manitoba side of the Manitoba-Saskatchewan border. The EOG Pipeline was therefore situated entirely within Manitoba. MIPL would then flow the gas from the Manitoba riser facility into Saskatchewan to be further processed and eventually sold to consumers.

The National Energy Board had already refused jurisdiction over the EOG Pipeline. ${ }^{112}$ The applicants sought to judicially review the Manitoba Minister's decision to grant a permit for the EOG Pipeline on the ground that the Minister had no jurisdiction.

The Court easily concluded that the EOG Pipeline was not part of a "single federal undertaking” (the primary test). ${ }^{113}$ The Court then considered whether the EOG Pipeline would be integral to the MIPL pipeline so as to constitute part of the federal undertaking (the secondary or derivative test). The Court concluded that the EOG Pipeline was a small part of EOG's Manitoba business, rather than an undertaking on which the MIPL interprovincial pipeline was dependant. Even though the EOG Pipeline was the only pipeline then planned to deliver natural gas to the MIPL facility, the MIPL facility was designed to accept natural gas from a number of producers. This was in contrast to the Dome case, the Court said, where the interprovincial pipeline system could not function without the provincial storage cavern. The EOG Pipeline was thus properly within the Manitoba Minister's jurisdiction. ${ }^{114}$ 108 TransAlta, supra note 105 at para 37, quoting Liquor Control Board of Ontario v Magnotta Winery
Corp, 2010 ONCA 681, 102 OR (3d) 545 at para 38.

2014 MBQB 19, 302 Man R (2d) 72 [Daniels].

110 


\section{iX. Aboriginal Law}

\section{A. BEHN V. Moulton Contracting LTD. ${ }^{115}$}

Duty to consult exists to protect the collective, not individual, rights of Aboriginal people

\section{BACKGROUND}

This Supreme Court of Canada case considers who has standing to assert Aboriginal rights to consultation and, by inference, provides some guidance to industry about who to consult with when the Crown has delegated its obligations to the industry proponent.

\section{FACTS}

The Crown granted Moulton Contracting Ltd. (Moulton) a licence to harvest timber in two areas of Fort Nelson First Nation (FNFN) territory. The licence authorized harvesting of timber across the Behn family trapline. The Behns were members of the FNFN. A number of individuals from FNFN blocked Moulton's access to the logging sites. Moulton brought a tort claim against these individuals, who defended on the basis that the licences were invalid because they had not been adequately consulted and their treaty rights had been violated. Moulton filed a motion to strike these defences. The motion made its way to the Supreme Court of Canada.

\section{DECISION}

The Supreme Court held that the duty to consult exists to protect the collective rights of Aboriginal peoples and therefore the duty is owed to the Aboriginal group that holds the section 35 rights. ${ }^{116}$ An Aboriginal group can authorize an individual or organization to represent it for the purpose of asserting its section 35 rights, but an individual member cannot assert a breach of a duty to consult on his or her own. ${ }^{117}$

However, the Supreme Court refused to address when a member of an Aboriginal group has standing to assert individual rights that arise from collective Aboriginal rights - for example, a person's individual right to hunt and trap. This was unnecessary in light of the Court's decision that the licence invalidity defences must be struck for abuse of process. ${ }^{118}$ Rather than attempting to challenge the licences in the appropriate legal forum - where legal issues like standing could be more appropriately addressed — the band members raised a breach of the duty to consult only as a defence to a tort claim. This was an abuse of process:

To allow the Behns to raise their defence based on treaty rights and on a breach of the duty to consult at this point would be tantamount to condoning self-help remedies and would bring the administration of justice 
into disrepute. It would also amount to a repudiation of the duty of mutual good faith that animates the discharge of the Crown's constitutional duty to consult First Nations. ${ }^{119}$

\section{COMMENTARY}

This case indicates that there is no obligation to address consultation issues with individual First Nations members, but instead with the group collectively. In practice, to ensure the appropriate discussions occur, it is important to understand whether a particular First Nation has authorized a person to represent it for the purposes of consultation/discussions and meet with those individuals accordingly.

\section{B. Moulton Contracting LtD. V. BRITISH COLUMBIA ${ }^{120}$}

Successful claim of damages against the Crown for failure to warn (unsuccessful against Band for interference with economic relations)

\section{BACKGROUND}

The Behn case before the Supreme Court of Canada addressed only an application to strike the FNFN individual defendants' allegations that the licences were invalid because of inadequate consultation. In the trial of Moulton's claim against both the Crown (in contract and tort) and members of the FNFN (in tort), the British Columbia Supreme Court awarded Moulton \$1.75 million in damages against the Crown. ${ }^{121}$ The Court dismissed Moulton’s claims against the First Nations defendants. We rarely see cases addressing the appropriate remedy for an industry proponent where it has been unable to extract resources due to subsequent First Nations objections, so this case offers an important illustration. Note, however, that this case is currently under appeal to the British Columbia Court of Appeal. ${ }^{122}$

\section{DECISION AND COMMENTARY}

The Court held that to give business efficacy to the licences between the Crown and Moulton, it was necessary to imply the following terms: “a) [t]hat the Province had engaged in all necessary consultation ... and had discharged its duty to consult; b) that the Province was not aware of any First Nations expressing dissatisfaction with the consultation undertaken by the Province, save as the Province had disclosed to Moulton.”"123

The Court found that the Crown had breached both of these implied terms, and was also concurrently liable to Moulton in tort for breach of a continuing representation and in failing to have warned Moulton of Mr. Behn’s intent to block Moulton’s access. ${ }^{124}$

\footnotetext{
$119 \quad$ Ibid at para 42.

1202013 BCSC 2348, 58 BCLR (5th) 70 [Moulton].

$121 \quad$ Ibid at para 3.

122 See Moulton Contracting Ltd v Behn, 2014 BCCA 134, 353 BCAC 289 (British Columbia’s successful application to be added as a respondent).

$123 \quad$ Moulton, supra note 120 at para 291.

$124 \quad$ Ibid at para 3.
} 
In finding that the Crown had breached its duty to consult with FNFN, ${ }^{125}$ the Court made a number of statements that should be noted by those dealing with requests for capacity funding. In particular, the Court was concerned that the Crown knew that the FNFN Lands Department had no ability to undertake meaningful evaluation of forestry proposals but did not adequately accommodate the situation. ${ }^{126}$ The Court was clear there was no obligation to provide funding for improved capacity, ${ }^{127}$ but held that, in light of the situation, the Crown should have broadened the informational component and provided extensions of time as necessary. ${ }^{128}$ The Court specifically criticized the Crown for proceeding with the sales before habitat information was available to both parties. ${ }^{129}$

However, in spite of the Crown's breach of the implied term, there was no evidence of a causal connection between the Crown's inadequate consultation and Moulton's losses: it appeared that the individual FNFN members would have set up the blockade even if the consultation had been adequate. ${ }^{130}$ The claim was also subject to an exclusion clause absolving the Crown from liability for blockades, which precluded much of Moulton's claim. ${ }^{131}$

On the other hand, the Court did find a link between Moulton's damages and the Crown's failure to disclose to Moulton the fact that Mr. Behn was threatening to block physical access to the area: ${ }^{132}$ had Moulton been aware of the potential blockade, it would not have pursued logging under the licence and would instead have pursued other opportunities with its usual sources of contract work. ${ }^{133}$ Damages were awarded on the basis of lost alternative opportunities (rather than lost profits from being unable to harvest timber under the licence). While no evidence had been adduced specifically on this point, the Court examined Moulton's historical patterns of earnings and operating expenses and awarded damages on that basis. ${ }^{134}$

Against the FNFN defendants, Moulton was unable to prove an unlawful act (under the pre-AI Enterprises test). ${ }^{135}$ The Court rejected the argument that the members were guilty of criminal mischief, ${ }^{136}$ on the facts Moulton's own use of the road was in violation of statute, ${ }^{137}$ and there was no law expressly forbidding the use the FNFN defendants made of the road. ${ }^{138}$ The FNFN defendants were not liable under civil conspiracy because the predominant purpose of their actions was to protest lack of consultation and infringement of Aboriginal rights rather than injure Moulton. ${ }^{139}$

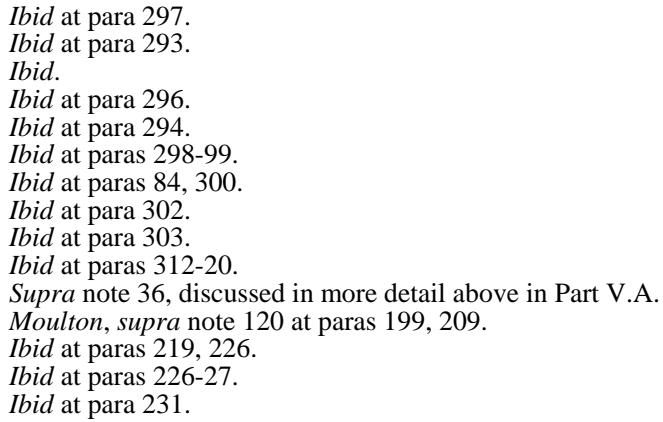




\section{Penn West Petroleum LtD. V. Bernard OMinayaK ${ }^{140}$}

Order to remove road blockade so mineral rights holder can access its drilling site

As is the Behn case, Penn West was an action arising out of a roadblock erected by First Nation persons. The defendants self-identify with the "Lubicon Lake Nation” (LLN) (a group not recognized by the federal or provincial Crowns but which asserts that it is the proper Chief and Council of the Lubicon Lake Cree people). LLN's position was that mineral and surface rights granted by the Alberta Crown to Penn West were invalid and nullities, on the basis that they had not been adequately consulted and had not consented to oil and natural gas development on their traditional lands. Hall J. of the Alberta Court of Queen's Bench applied the reasoning in Behn, and held that the appropriate manner for LLN to have made such arguments would have been to object to the drilling licences or access permits granted to Penn West. As in Behn, to allow LLN to make such arguments in opposition to an order requiring the removal of the roadblock would be an abuse of process.

The Court then granted an order under section 54.03 of Alberta's Public Lands Act, which provides that where a person has "been prevented from gaining access to a closed road or from having free access to, passage on or over or use of a highway, road or trail," that person or the Crown may apply to the Court for an order prohibiting the interference with that use. ${ }^{141}$ Significantly, from a practice perspective, the Public Lands Act does not require an applicant to demonstrate irreparable harm, nor does it require a review of the balance of convenience - accordingly, in the right circumstances, it may be easier to obtain relief from a road blockade under this statutory authority than it would be through an injunction.

\section{DENE THA' FIRST NATION V. BRITISH COLUMBIA (MINISTER OF ENERGY AND MINES) ${ }^{142}$}

\section{Crown satisfied its duty to consult over the sale of subsurface oil and gas tenures}

The Dene Tha' First Nation (DTFN) sought judicial review of Crown dispositions of oil and gas leases and licences on DTFN Treaty 8 traditional territory. While the leases and licences do not authorize any exploration or extraction activities, and holders must apply to the Oil and Gas Commission to actually conduct any development activity on the land, the Court held that the duty to consult is still owed prior to the issuance of the leases and licences. ${ }^{143}$ In assessing the scope of its duty to consult, the Crown was obligated to consider the potential adverse impact on DTFN treaty rights. ${ }^{144}$ The Crown considered potential impacts to be low ${ }^{145}$ and the Court accepted this conclusion and the mid-level consultation that followed ${ }^{146}$ — but importantly in the context that there will be "an ongoing process of consultation as development proceeds."147 
The Court held that the Crown's policy decision to pursue shale gas development was not at issue: "[t]hat is for the legislature to decide."148 The Court also rejected the DTFN's argument that the Crown was obligated to accommodate, at the disposition of tenures stage, "the broader strategic implications of selling the tenures, including all direct, indirect, cumulative and derivative impacts of the proposed action."149

However, the Court specifically highlighted the need for ongoing consultation as the development process unfolds and demonstrated that the Courts (at least in British Columbia) are alive to cumulative impact concerns:

\begin{abstract}
I have concluded that the process in which the Crown has engaged to date complies with these guidelines in so far as the June 2010 dispositions are concerned. But the appropriate depth of consultation will likely become greater, not lesser, as the process continues, as existing parcels proceed into development and further parcels are sought for disposition. The question posed by Chief Ahnassay ["Is there enough land within the vicinity of the Parcel Sales (assuming development of shale gas and other resources) on which our First Nation can meaningfully exercise our rights now and into the future”] has been answered for the time being, but it was neither possible nor feasible to answer it once for all time. It remains alive and will have to be addressed again as development expansion is proposed, to ensure that the Dene Tha' can continue to exercise their treaty rights meaningfully. Only in that way will the honour of the Crown be maintained. ${ }^{150}$
\end{abstract}

\title{
E. BUFFALO RIVER DENE NATION V. SASKATCHEWAN (MINISTER OF ENERGY AND RESOURCES) $)^{151}$
}

\section{Crown has no duty to consult over disposition of Oil Sands Special Exploratory Permits}

In direct contrast to the British Columbia Court's decision in Dene Tha' above, the Saskatchewan Court of Queen's Bench held that the Minister of Energy and Resources had no obligation to consult with the Buffalo River Dene Nation about its sale of Oil Sands Special Exploratory Permits in the Treaty 10 area. In coming to this conclusion the Court relied heavily on the fact that (1) the permits do not authorize the permit holder to go onto the land (additional approvals are required for that), ${ }^{152}$ and (2) this was not a policy or strategic planning decision over which a duty to consult is owed because "the decisions involved no planning." "153 There is definitely a question about whether this case is in line with authorities ${ }^{154}$ and industry should not consider this matter settled until the issue is addressed by an appellate court.

\footnotetext{
$148 \quad$ Ibid at para 5.

$149 \quad$ Ibid at para 109

150 Ibid at para 135 (Chief Ahnassay’s question appears at para 123 [emphasis omitted]).

1512014 SKQB 69, [2014] 3 CNLR 10

$152 \quad$ Ibid at paras 18-27, 38-42.

$153 \quad$ Ibid at para 31.

154 As Nigel Bankes recently argued in his case comment, Nigel Bankes, "Crown Oil Sands Dispositions and the Duty to Consult” (22 April 2014), online: Ablawg <ablawg.ca/2014/04/22/crown-oil-sands-
} dispositions-and-the-duty-to-consult/>. 


\section{STATUTORY INTERPRETATION}

\section{A. ENBRIDGE GAS NEW BRUNSWICK LIMITED PARTNERSHIP V. NEW BRUNSWICK (ATTORNEY-GENERAL) $)^{155}$}

Regulations struck down for being ultra vires legislative mandate

This case dealt with the specific issue of whether section 52(5)(a) of the Gas Distribution Act, $1999^{156}$ empowered the Lieutenant Governor in Council to require through regulation that the New Brunswick Energy and Utilities Board apply a particular revenue to cost ratio ${ }^{157}$ when fixing rates and tariffs for the sale of natural gas.

Section 52(5)(a) provided generally that the Board "shall adopt the methods and techniques prescribed by regulation”; section 95(1)(m.2) authorized the Lieutenant Governor in Council to adopt a regulation prescribing the methods or techniques the Board must adopt when approving or fixing rates. ${ }^{158}$ The New Brunswick Court of Appeal concluded that this language was not sufficient to authorize the Lieutenant Governor in Council to prescribe a specific revenue to cost ratio by regulation: the language "methods and techniques" used in the empowering Act was not given a broad interpretation. ${ }^{159}$

The second issue dealt with by the Court of Appeal — a practice point — was addressed in obiter but resulted in split reasons. The majority said that Enbridge should have brought its legislative challenge first to the Board, with the Court reviewing the Board's decision potentially on a standard of reasonableness. ${ }^{160}$ The minority disagreed strongly with this position. $^{161}$

This case serves as a reminder that governments sometimes pass regulations that are not specifically authorized by a legislative grant of authority. Lawyers should review empowering legislation critically when administrative regulations and orders may negatively impact their clients. At the same time, it is important to note that the legislature can remedy defects in regulations. Whenever a party challenges legislation, the power rests with the respondent government of the day to declare "black is white” and specifically extinguish the challenging party's remedy. It can even do so retroactively.

Régie des rentes du Québec v. Canada Bread Company Ltd., a recent case from the Supreme Court of Canada, specifically says that it is within the legislature's prerogative to enter the domain of the courts and offer a binding interpretation of its own law by enacting declaratory legislation. ${ }^{162}$ This legislation has immediate effect on pending cases and is therefore an exception to the general rule that legislation is prospective. Whatever views one

\footnotetext{
1552013 NBCA 34, 404 NBR (2d) 189 [Enbridge].

SNB 1999, c G-2.11, s 52(5(a).

Rates and Tariffs Regulations - Gas Distribution Act, 1999, NB Reg 2012-49 ("revenue to cost ratio not exceeding 1.2:1 for any class of customers," s 4(1)).

Gas Distribution Act, 1999, supra note 156, ss 52(5)(a), 95(1)(m.2).

Enbridge, supra note 155 at paras 10-11.

Ibid at paras 14-16.

Ibid at paras 19-25.

2013 SCC 46, [2013] 3 SCR 125 at para 26.
} 
may have about whether the legislature's use of this extraordinary power is consistent with the rule of law, lawyers have to be alive to its potential use and mindful of the fact that it is not uncommon for it to be used in Alberta. ${ }^{163}$

\section{STANDARD OF REVIEW}

A. SHIN HAN F \& P INC. V. CANADA-NoVA SCOTIA OFFSHORE PETROLEUM BOARD ${ }^{164}$

\section{Standard of review applicable to Board decision to cancel a licence is reasonableness}

This is the first case considering the standard of review applicable to decisions of the Canada-Nova Scotia Offshore Petroleum Board. The Board had refused Shin Han's request for an extension of time to pay a required deposit, a condition of Shin Han's Exploratory Licence. Shin Han sought judicial review of the Board's subsequent decision to cancel the Licence. Unsurprisingly, ${ }^{165}$ the Court concluded that the standard of review was reasonableness since deference will usually result where the tribunal is interpreting its home statute. ${ }^{166}$ The Court denied Shin Han's application, and made the following comments about the Board's expertise:

I conclude that the Parliament of Canada and the Nova Scotia legislature have created a discrete administrative regime, with administrative and technical expertise, together with a broad mandate to manage the development of Nova Scotia's offshore petroleum resources. The Board is mandated to grant and cancel exploration licenses to further the purposes of the Accord as well as the Federal and Nova Scotia Acts. The administration of the Acts involves public policy, and the legislation anticipates that the Board will exercise significant expertise in that administration. ${ }^{167}$

\section{B. AREVA RESOURCES CANADA INC. V. SASKATCHEWAN (MINISTER OF ENERGY AND RESOURCES) $)^{168}$}

\section{Standard of review applicable to Minister's mineral royalty decision is reasonableness}

Areva made non-arm's length sales of uranium from 2006 to 2009. The Crown Mineral Royalty Schedule, 1986, gives the Saskatchewan Ministry of Energy and Resources jurisdiction to interpret and calculate the term "average sales price" as set forth in the

See e.g. Calgary (City) v Alberta (Minister of Municipal Affairs), 2008 ABQB 433, [2008] AJ No 776 (QL) [Calgary] and the Enabling Regional Growth Boards Act, SA 2013, c 17, both of which involved retroactive legislation passed in the face of ultra vires court challenges to regulations. In both cases the legislation retroactively validated the regulations in issue and extinguished the existing court actions. In the Calgary case, the Alberta Government even sought costs (unsuccessfully) on the basis that it was the successful party because the Court was required by legislation to dismiss the action!

2013 NSSC 341, 335 NSR (2d) 181 [Shin Han].

Given the Supreme Court of Canada's jurisprudence and the finding made by the Newfoundland Court of Appeal in Hibernia Management and Development Co v Canada-Newfoundland Offshore Petroleum Board, 2008 NLCA 46, 277 Nfld \& PEIR 248 about the standard of review (reasonableness) applicable to the Canada-Newfoundland and Labrador Offshore Petroleum Board, established by a similar statutory scheme.

166 Shin Han, supra note 164 at para 37, citing Dunsmuir v New Brunswick, 2008 SCC 9, [2008] 1 SCR 190.

167 Shin Han, ibid at para 56. 
legislation. ${ }^{169}$ The Ministry did so and then used that determination as part of its determination of fair market value for the purpose of calculating the royalties payable. The Saskatchewan Court of Appeal held that the Ministry's determination was reviewable on a standard of reasonableness. ${ }^{170}$

\section{COMPETITION LAW}

\section{A. TERVITA CORP. V. COMMissioner OF COMPETITION ${ }^{171}$}

Competition Tribunal can make a remedial order under section 92 where competition will be prevented within a reasonable period of time following merger

\section{BACKGROUND}

This is one of the first cases to address the analytical framework required under section 92 of the Competition Act in assessing whether a merger "prevents" (rather than "lessens”) competition. ${ }^{172}$ It is currently on appeal to the Supreme Court of Canada. ${ }^{173}$

\section{2. $\quad$ FACTS}

Tervita Corporation, formerly known as CCS Corporation (Tervita), purchased the shares of Complete Environmental Inc. (Complete) in January 2011. Complete owned the Babkirk Site in North-Eastern British Columbia and intended to operate it largely as a bioremediation facility. But Complete also had a permit to operate a secure landfill at the Babkirk Site. Tervita owned the only other two secure landfills in the area (where oil and gas developers could dispose of their hazardous waste) and intended to operate the Babkirk Site as a secure landfill rather than a bioremediation facility. The Commissioner took the position that Tervita's purchase prevented or was likely to prevent competition under section 92 of the Competition Act and requested an order from the Competition Tribunal requiring Tervita to divest itself of its interest in the Babkirk Site.

The Tribunal granted the Commissioner's application. A major issue was that Complete had intended to operate the Babkirk Site as a bioremediation facility rather than a secure landfill at the time of the merger. The Tribunal concluded that, absent the sale to Tervita, Complete's bioremediation business would have failed within a relatively short period of time and either Complete or another purchaser would have begun operating a secure landfill in competition with Tervita - all in less time than it would have taken a new entrant to obtain the required permits and enter the secure landfill market. Tervita appealed to the Federal Court of Appeal.

Mineral Disposition Regulations, Sask Reg 30/86, Schedule, s 27(3)(a); ibid at para 92. Ibid at para 33.

2013 FCA 28, 446 NR 261 [Tervita].

RSC 1985, c C-34, s 92.

Tervita, supra note 171, leave to appeal to SCC Canada granted, 35314 (27 March 2014) and judgment reserved. 


\section{DECISION AND COMMENTARY}

The Federal Court of Appeal generally approved the Tribunal's analysis under section 92. The analysis need not be limited to considering whether competition was prevented immediately at the time of the merger. Instead, competition can be prevented by the merger where the potential entry or expansion of competition would likely have occurred within "a reasonable period of time" (absent the merger). ${ }^{174}$ This means that counsel, when considering Competition Act implications arising from a purchase or sale, should be sure to consider whether the transaction is likely to prevent competition beyond the immediate term.

Even where a merger prevents competition, section 96 provides that "[t]he Tribunal shall not make an order under section 92 if it finds that the merger ... is likely to bring about gains in efficiency that will be greater than, and will offset, the effects of any prevention or lessening of competition.”175 The Federal Court of Appeal held that the Tribunal had made a number of errors in its section 96 assessment. An assessment should be as objective and quantitative as possible, and, where the Commissioner has failed to adduce a sufficient quantitative analysis of the anti-competitive effects, these same quantifiable factors cannot instead be considered subjectively and qualitatively. ${ }^{176}$

Nonetheless, the Federal Court of Appeal upheld the Tribunal's order, concluding that the Commissioner's failure to quantify the anti-competitive effects of the merger did not mean these effects were zero, but that the weight to be accorded to them was undetermined. ${ }^{177}$ In this case, the Court conducted its own section 96 analysis and concluded that the gains in efficiency resulting from the merger (minor administrative overhead) were "marginal to the point of being negligible"178 and "it cannot be concluded that an anti-competitive merger may be approved under section 96 of the Competition Act if only marginal or insignificant gains in efficiency result from that merger." 179

Terivita, ibid at paras 86-94. The timeframe of "poised entry" must be discernible (but need not be precisely calibrated) and should normally fall within the temporal dimension of the barriers to entry into the market at issue.

Competition Act, supra note 172, s 96.

Terivita, supra note 171 at paras 127-30, 139-63, 168. The Court concluded at para 163 :

In this case, the Tribunal erred in law in its section 96 analysis, notably by accepting a defective

"deadweight" loss calculation, by using an overly subjective offset methodology, by treating as qualitative effects certain quantitative effects which the Commissioner had failed to quantify, and by referring to qualitative environmental effects that are not cognisable under the Competition Act. Ibid at para 167. 


\section{B. 321665 ALBERTA LTD. V. EXXONMOBIL CANADA LTD. ${ }^{180}$}

It is not a conspiracy to lessen competition for joint owners of oil and gas properties to decide to use a single company to provide certain oilfield services

\section{BACKGROUND}

A previous CELF update addressed the Queen's Bench decision in this case, ${ }^{181}$ which held Husky Oil Operations Ltd. (Husky) and ExxonMobil Canada Ltd. (ExxonMobil) liable to a former supplier of fluid hauling services under sections 45 and 36 of the Competition Act (conspiracy to unduly lessen competition). ${ }^{182}$ Husky and ExxonMobil had agreed to treat their facilities in the Rainbow Lake area as one operation and collectively chose one of two fluid hauling contractors to supply both companies. The excluded contractor sued, and damages were assessed at \$5 million. In light of the Queen’s Bench decision, the authors cautioned that "tenants in common conducting oil and gas operations should be aware of the provisions of the Competition Act to ensure that they do not violate these provisions when making decisions about how to conduct their operations.”183

\section{DECISION}

The Court of Appeal has now overturned the Queen's Bench decision. The Court of Appeal noted that the purpose of the Competition Act is to provide market participants a fair opportunity to compete and the plaintiff was provided this opportunity. ${ }^{184}$ The trial judge had erred in placing too much emphasis on the consequences for the plaintiff and had "lost sight of the true character of what Husky and [Exxon]Mobil were doing." 185 The Court reasoned, by analogy, that if Husky and ExxonMobil had jointly agreed to build a pipeline to meet their fluid hauling needs, the consequences to the plaintiff would have been the same and no one would have argued that the agreement was anti-competitive. ${ }^{186}$ The Court of Appeal concluded that Husky and ExxonMobil did not violate section 45 of the Competition Act and were therefore not liable to the Plaintiff:

We can discern no reason why Husky and Mobil should not be permitted to rationalize their operations, particularly when the purpose was to increase efficiencies and reduce unnecessary costs. To find otherwise would necessarily undermine the competitive nature of Husky and Mobil's operations by driving up their costs, and create unnecessary inefficiencies in a highly competitive industry that attempts to efficiently and effectively develop and produce scarce, natural resources. That cannot have been the intent of the Act. ${ }^{187}$

2013 ABCA 221, 553 AR 293, leave to appeal to SCC refused, 35529 (16 January 2014) [321665]. Gavin S Fitch \& Evan W Dixon, "Recent Regulatory and Legislative Developments of Interest to Energy Lawyers” (2012) 50:2 Alta L Rev 469 at 475-76.

Supra note 172, ss 36, 45.

Fitch \& Dixon, supra note 181 at 475.

321665 , supra note 180 at paras $20-22$.

Ibid at para 25.

Ibid.

Ibid at para 23. 


\section{COMMENTARY}

Section 45 of the Competition Act has now been amended ${ }^{188}$ and joint purchase arrangements are no longer caught by the criminal conspiracy provisions of the Competition Act. Rather than relying on the Alberta Court of Appeal's decision as providing significant guidance in this area ${ }^{189}$ counsel should be aware that previously-significant Queen's Bench precedent has been overturned.

\section{WORKPLACE AlCOHOL (DRUG) TESTING}

\section{A. Communication, ENERGy AND PAPERWORKERS UNion of CANAdA, Local 30 V. IRVING PULP \& PAPER, LtD. ${ }^{190}$}

\section{Employer cannot impose random alcohol testing absent evidence of a workplace problem with} alcohol use

\section{BACKGROUND}

The Supreme Court of Canada addressed whether an employer could impose random alcohol testing in a unionized workplace. The Court upheld a labour arbitration board's decision that Irving Pulp \& Paper Inc. (Irving) had exceeded the scope of its management rights under a collective agreement by imposing random alcohol testing in the absence of evidence of a workplace problem with alcohol use. ${ }^{191}$

\section{2. $\quad$ FACTS}

The collective agreement contained a typical management rights clause whereby the union "recognizes and acknowledges that it is the right of the Company to operate and manage its business subject to the terms and provisions of this agreement."192 In 2006, Irving implemented a drug and alcohol policy under which an employee would be subject to mandatory testing (1) if there was reasonable cause to suspect the employee of alcohol or other drug use in the workplace, (2) after direct involvement in a work-related accident or incident, or (3) as part of a monitoring program for an employee returning to work following voluntary treatment for substance abuse. ${ }^{193}$ Additionally, 10 percent of employees in safety sensitive situations would be randomly selected for unannounced breathalyzer testing over the course of a year. ${ }^{194}$ A positive test for alcohol would attract disciplinary action, including dismissal, and failure to submit to testing was grounds for immediate dismissal.

Budget Implementation Act, SC 2009, c 2, s 410.

In our view, the appellants were correct to assert that the Court's analysis should have been on whether the agreement resulted in an undue reduction in competition for the purchase of fluid hauling services rather than for the supply of those services (see 321665, supra note 180 at para 33). But the Court of Appeal appears to have overturned the Queen's Bench decision on the basis that Husky and ExxonMobil had not conspired to unduly lessen competition between suppliers of services (see ibid at para 23), and then declined to address (while questioning) the other aspects of the trial decision. 2013 SCC 34, [2013] 2 SCR 458 [Irving].

Ibid at para 8 .

Ibid at para 21.

Ibid at para 12

Ibid at para 10. 
After a teetotaller who had not had a drink since 1979 was randomly tested, the union filed a grievance challenging Irving's requirement that 10 percent of employees be subject to randomly selected unannounced breathalyzer testing.

\section{DECISION}

The Supreme Court considered whether unilaterally implementing a random alcohol testing policy was a valid exercise of Irving's management rights under the collective agreement. ${ }^{195}$ In a 6-3 split decision, the Court concluded that it was not.

Both the majority and minority gave significant deference to the arbitral consensus that had arisen on this issue: their difference lay in what that consensus was. The majority held that universal mandatory random alcohol testing could not be permitted in a unionized workplace unless either (1) it had been negotiated into a collective agreement, ${ }^{196}$ or (2) there was evidence of a general problem of alcohol abuse in the workplace. ${ }^{197}$ In this case, the Supreme Court deferred to the arbitration board's conclusions that eight incidents over a 15 year period did not reflect a significant problem. ${ }^{198}$

The following can be taken from this decision, which should assist counsel in their assessment of labour relations issues:

- The Supreme Court approved the “KVP Test” applied in labour arbitration: "any rule or policy unilaterally imposed by an employer and not subsequently agreed to by the union, must be consistent with the collective agreement and be reasonable.”199

- Breathalyzer testing effects a "significant inroad” on employee privacy. ${ }^{200}$

- In applying the KVP Test in matters affecting employee privacy, it is necessary to engage in a balancing of interests. ${ }^{201}$ An employer may be justified in imposing random alcohol testing if "it represents a proportionate response in light of both legitimate safety concerns and privacy interests."202

- Employers are generally entitled to test individual employees who occupy safety sensitive positions in dangerous workplaces without exhausting alternative methods "if there is 'reasonable cause' to believe that the employee is impaired while on duty, where the employee has been directly involved in a workplace accident or significant incident, or where the employee is returning to work after treatment for substance abuse." 203 
- The fact that a workplace is dangerous is not automatic justification for random testing with disciplinary consequences. This can only be justified where there is "evidence of enhanced safety risks, such as evidence of a general problem with substance abuse in the workplace."204

- The Court recognized there may be extreme circumstances where a "highly safety sensitive” or "inherently dangerous" work environment justified random alcohol testing without evidence of a general problem with alcohol abuse, but the Court did not decide the point. ${ }^{205}$

\section{COMMENTARY}

While this case was determined in the context of a unionized workforce through the grievance process, it seems likely that attempts to implement random alcohol testing in a non-unionized workplace would attract a similar analysis and balancing of employees' privacy rights against the employer's ability to implement reasonable and proportionate measures in the workplace to promote safety and protect its property. Employers may also find it harder to convince a decision-maker that a random drug testing regime is proportionate (and accordingly justified) given the relatively greater infringement of privacy rights in drug testing (via urinalysis) as opposed to alcohol testing (via breathalyzer), and given that a positive drug test result may be less indicative of increased workplace risk than a positive alcohol test (in that drug testing, unlike breathyzer testing, tests for past usage and not current impairment). ${ }^{206}$ Results of "for cause" and post-incident alcohol and drug testing may be an employer's best evidence of a "general problem with substance abuse in the workplace” which might ultimately justify random testing.

\section{SALES TAX}

\section{A. HUSKY OIL OPERATIONS LTD.}

\section{SASKATCHEWAN (MINISTER OF FINANCE) $)^{207}$}

Sales tax treatment of cement and additives used in oil and natural gas wells

This long-awaited decision may finally resolve the issue of the tax treatment of cement and additives injected into well bores during servicing, repair, and abandonment. Saskatchewan provincial sales tax (PST) is payable by the "user" or "consumer" of tangible personal property. Between 1996 and 2001, third-party service contractors collected PST on cement and additives supplied and used by them on Husky-owned oil and natural gas wells, and remitted that PST to the Saskatchewan government. Husky applied for a refund of that PST, essentially on the basis that the cement and additives were consumed or used by the third-party contractors, and that there was, therefore, no sale of personal property from the

\footnotetext{
$204 \quad$ Ibid at para 31.

$205 \quad$ Ibid at para 45

206 See e.g. Suncor Energy Inc v Unifor Local 707 A, 2014 ABQB 555, [2014] AJ No 1025 (QL), for postIrving grievance arbitration rejecting Suncor's attempt to impose random drug testing on Fort McMurray oilsands workers.

207 Husky Oil Operations Ltd v Saskatchewan (Minister of Finance), 2014 SKQB 116, [2014] SJ No 234 (QL) [Husky].
} 
third-parties to Husky which would properly attract PST. Saskatchewan Finance denied the refund and Husky sued.

Dawson J. of the Saskatchewan Court of Queen's Bench dismissed Husky's claim, holding that: (1) the particular contracts between Husky and the third-party contractors, properly construed, provided for the sale of materials (cement and additives) by the thirdparties to Husky; ${ }^{208}$ and (2) in any event, Husky was the ultimate user and consumer of the cement and additives. ${ }^{209}$ In doing so, the Court distinguished the decision of the British Columbia Supreme Court in Burlington Resources Canada Ltd. v. British Columbia, ${ }^{210}$ in which that Court determined that, rather than a sale of cement, the supply of cement to Burlington was incidental to the service contracts and therefore not subject to PST.

The Saskatchewan Court based its decision in large part on the particular provisions of the contracts between Husky and the third-party contractors. Together with the contrary result in Burlington based on the particular wording of that contract, this may mean that producers are left with little definitive guidance on whether cement and additives used in their wells is or is not subject to PST (except, presumably, to the extent that their contracts with third-party well-servicing contractors precisely mirror the contracts between Husky and its contractors). We understand that more than 40 energy exploration companies had filed similar claims for the return of PST on the cement and additives used in their wells in the Saskatchewan Court, and that those actions have been essentially in abeyance pending the decision in Husky. It will remain to be seen whether the Husky decision is dispositive of those pending cases.

\section{Administrative Tribunal Leave to Appeal Procedure}

\section{A. FORT MCKAY FIRST NATION V. ALBERTA ENERGY REGULATOR 211}

Time for leave to appeal an AER interlocutory decision may not start to run until the final decision is rendered

Slatter J.A. granted the Fort McKay First Nation leave to appeal the Energy Resources Conservation Board (ERCB) and Alberta Energy Regulator (AER) decisions approving the Brion Energy Corporation (formerly Dover Operating Corp.) oil sands project. Leave was granted on whether the ERCB had construed its jurisdiction to answer constitutional questions too narrowly. The ERCB had concluded it did not have jurisdiction to consider whether the project would constitute a prima facie infringement of the First Nation's treaty and constitutional rights.

The Fort McKay First Nation has abandoned its appeal, so we will not get the benefit of the Court of Appeal's opinion on the AER's jurisdiction over Aboriginal constitutional issues, but Justice Slatter did make some important findings about how long project opponents have to challenge regulatory decisions. 
The governing legislation gave the First Nation one month from when the decision was made to file and serve the application for leave to appeal. ${ }^{212}$ The timeline was as follows:

- 18 April 2013: the ERCB ruled on its jurisdiction in an interlocutory decision.

- 23 May 2013: the ERCB provided written reasons for its decision on jurisdiction.

- 6 August 2013: the AER (successor to the ERCB) made its final decision granting project approval. ${ }^{213}$

- $\quad$ September 2013: the Fort McKay First Nation filed and served its application for leave to appeal on the question of ERCB jurisdiction.

Was Fort McKay First Nation out of time, given that the decision it was seeking leave to appeal was made on an interlocutory basis in April 2013? The Court said "No.” Justice Slatter recognized that complex project approvals often lend themselves to being decided in stages. He held that in the interest of discouraging interlocutory appeals, the final decision should be regarded as incorporating by reference all of the interlocutory decisions that preceded it. ${ }^{214}$ Time to appeal the interlocutory decisions then begins to run from the date of the final decision, and Fort McKay was in time with its application for leave. ${ }^{215}$

The take-away from this decision is that failing to seek leave to appeal a regulator's interlocutory decision may not end the matter. The time period for seeking leave to appeal may not begin to run until the regulator issues its final decision. Act General Regulation, Alta Reg 90/2013, s 5(1).

213 Dover Operating Corp Application for a Bitumen Recovery Scheme Athabasca Oil Sands Area, (6 August 2013), 2013 ABAER 014, online: AER <www.aer.ca/>. 